\title{
A questão regional: a hegemonia inacabada
}

\section{FRANCISCO DE OLIVEIRA}

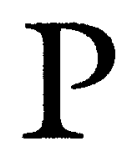

or trás das recentes, e gravemente crescentes, manifestaçōes de separatismo dos Estados do Sul e Sudeste do Brasil, que poderíamos chamar o separatismo dos ricos, espreita a Questão Regional, a fratura na unidade nacional constituída desde o século XIX, a qual algumas vezes esteve próxima de consolidação e hoje apresenta-se com perdão da analogia ortopédico-traumática - em estado de fratura exposta. Ela é da mesma natureza que a guerra civil entre o IRA e a ocupação inglesa na Irlanda, o separatismo da Liga Lombarda na Itália e a limpeza étnica na ex-Iugoslávia. Revela o fracasso das soluçóes para a unidade nacional, não moldadas em algo que terminou com o que são, hoje, a autonomia das regióes, no modelo espanhol, ou dos länder, na Alemanha Federal.

A Questão Regional há muito deixou de ser considerada uma questão nacional. Depois da derrota, em 1964, das forças sociais e políticas às quais deveu seu nascimento e seu auge, a SUDENE - o último grande esforço e momento de sua importância nacional - prosseguiu num êxito administrativo que, ironicamente, iria marcar mais fundo seu fracasso político. Na ditadura, a Questão Regional, enquanto tal, deixou de existir e foi rebaixada a planos administrativos, banhados em crocodílicas lágrimas de generais-presidentes nas épocas das secas. Entre um regime carente de legitimidade e políticos faltos de representatividade, os planos regionais foram abastardados como moeda de troca que, de um lado, ajudava a manter a fachada das instituiçóes representativas $e$, de outro, a fazer de conta que o regime era racional, para lograr empréstimos e financiamentos dos Bancos Mundial e Interamericano de Desenvolvimento. Assim, a ditadura obtinha recursos externos para financiar a expansão capitalista onde lhe interessava, utilizava-os para tratar dos problemas de balanço de pagamentos, e pagava aos politicóides locais com a moeda podre do novo clientelismo, com o álibi da promoçáo da desconcentração da renda na regiāo mais miserável do país. Mas não se tratava de pacto, nem de negócios de ingênuos: o que estava em operação de todos os lados - Bancos Mundial e Interamericano incluídos era salgar a terra do Nordeste, para matar a erva daninha da subversão social. 
O sucesso da SUDENE sob a ditadura foi enorme, mas o Nordeste transformou-se num gueto de nordestinos. Uma armadilha da história, se é permitido falar assim, ainda, dessa deusa a pregar peças às motivaçóes mais radicais: o êxito da SUDENE marca o ponto de inflexão da presença de nordestinos na política nacional, e o abastardamento tanto da Questão Regional quanto da política. Comparando-se com o passado mais longínquo, ou mais recente pré-64, não há, hoje, qualquer grande político nacional que tenha construído sua reputação fazendo carreira no Nordeste, nem os políticos nordestinos participam do debate nacional; ou, dizendo de outro modo, não há político algum do Nordeste que consiga alçar-se à condição de liderança nacional. Estão imersos num mesquinho e limitado debate - se aquilo pode ser chamado por esse nome - regional, ou, na maior parte das vezes, meramente local. Sarney não é contra-exemplo, pois não passou de um acidente do descalabro do Hospital de Base de Brasília; da teimosia de Tancredo em esconder uma doença que, se tratada a tempo, provavelmente teria desenlace menos fatal a tão curto prazo; e do descaso que o presidencialismo dá ao cargo de vice-presidente. Nessa condição, cumprindo veredicto do próprio Tancredo, pois o Nordeste era o país do PFL, foi escolhido para estruturar a malfadada Aliança Democrática. Collor, então, é ainda menos emblemático; não foi por ter sido governador de Alagoas que chegou à presidência. Tal fato é imediatamente claro para todos, sem a necessidade de perder-se mais tempo com outras consideraçóes.

No campo intelectual, a Questão Regional sempre foi tratada por nordestinos. Nenhum intelectual de fora do Nordeste ou da Amazônia abalançou-se a temas regionais ou à Questão Regional propriamente dita. Não há erro possível: percorra-se a bibliografia, ou freqüente-se qualquer das reuniōes das grandes sociedades científicas das áreas humanas e sociais, tais como ANPOCS, ABAS, SBS, SBPC. Nestas, quando se estiver tratando de algum tema regional, haverá apenas nordestinos. No caso amazônico, como a ecologia está em moda, há os verdes que são transamazb́nicos em sentido bem irônico e verdadeiro: eles reduzem a Amazônia a uma questão de ecologia. Ironicamente, ninguém menos que Celso Furtado não tem qualquer produção sobre a Questáo Regional que se equipare à sua produção sobre a economia brasileira. A rigor, ele percebe a Questão Regional em termos de um diagnóstico, o qual foi a base da criação da SUDENE, com todos seus explosivos ingredientes, mas inverte a equação: a migração de nordestinos estaria fazendo baixar o salário real dos trabalhadores da nova industrialização no Centro-Sul, considerada como ameaça à unidade nacional, 
ao invés de solução para a questáo da mão-de-obra, clássico componente, desde o século XIX, da Questão Regional!

\section{A Questão Regional: \\ a unidade nacional mal resolvida}

A Questáo Regional é, antes de tudo e sobretudo, o caso de uma unidade nacional mal resolvida. Tal como as clássicas questōes regionais no mundo - Mezzogiorno, Sul dos Estados Unidos rigorosamente até as medidas do New Deal e à saga dos direitos civis, particularmente a integração racial -, no fundo da Questão Regional tipicamente brasileira jaz uma questão agrária irresoluta, de par com a do mercado de força de trabalho. As duas formam uma unidade inextricável, e suas gêneses são praticamente simultâneas em forma e fundo: a de uma nova forma de produção de mercadorias.

Mas um dos mitos brasileiros mais bem-construídos é o de que resolvemos bem a unidade nacional. Preservou-se um imenso território, que na independência passa integralmente à nova nação, ao contrário do estilhaçamento que ocorre com as ex-colônias do Império Espanhol, na verdade já divididas, por necessidades e estratégia da exploraçáo colonial em alguns vice-reinados. Uma língua unifica de norte a sul e de leste a oeste o vasto território; língua com vocação hegemônica, devido ao peso da economia, das instituiçóes, da Igreja, da destruição das sociedades tribais, mas ainda é uma língua minoritária, levando-se em conta não apenas os ainda vastos contingentes das naçóes indígenas, como os novos contingentes negros, que traziam nova contribuiçăo lingüística. Outra vez não se levou em consideraçáo, na construçăo do mito, que do México à Patagônia, com as exceçōes inglesa, francesa e holandesa do Caribe, a língua com vocação igualmente hegemônica era o espanhol, o que não impediu a fragmentação das ex-colônias em mais de vinte novos países independentes, todos eles tendo adotado a forma republicana.

Justamente aqui comparece o outro grande mito da unidade nacional, e que mais de perto começa a ter relaçáo com o tema da Questáo Regional. A Coroa nascente, prolongação dos Bragança que saíam com a Independência, temperada e condicionada pelas novas forças sociais e políticas construídas ao longo da própria colonização, é uma das garantias da unidade nacional, ou pelo menos, do reconhecimento imediato, pelas grandes potências européias, da nova naçáo. A diplomacia dos casamentos dinásticos evita que as principais potências, monarquias ainda absolutamente absolutistas - apenas a Inglaterra já havia abandona- 
do esse pelotáo - tomem o partido de Portugal. Os Estados Unidos também tomam o partido brasileiro, mas por razóes diferentes das européias. As razōes inglesas são menos dinásticas e mais econômicas, como a história já se cansou de reconhecer.

A tese vale no que diz respeito ao reconhecimento da independência, e menos à manutenção da unidade nacional. Com toda a reverência que se deve ao trabalho de Luiz Felipe de Alencastro, o mais notável renovador da interpretação da história brasileira depois de Fernando Novaes, dessa renovação deve-se valorizar a questáo da formaçăo do Estado nacional, o ponto forte de sua tese de doctorat $d$ 'État, e relativizar o ponto de vista sobre a unidade nacional a partir da continuidade dinástica, que é apenas cereja em cima do pudim.

A unidade nacional será o resultado do processo de competiçăo entre burguesias nascentes, de um lado, $\mathrm{e}$, de outro, das alianças que elas conseguem estabelecer com uma burocracia imperial propriamente dita. Esse processo inclui a formação das principais instituiçōes do próprio Império, no bojo da burocracia, inclusive Exército e Marinha, cujo papel extraordinário na organização da concorrencia foi justamente romancendo - e ideologizado - pela epopéia da unidade nacional. Uma das burguesias nascentes sedia-se no Rio, é já a proprietária da cafeicultura em expansão - advertência aos que podem (ou querem) ver neste ensaio uma catilinária bobamente antipaulista - e faz aliança com os negreiros os quais haviam transformado o Rio em principal praça comercial das peças d'África, uma das fontes da acumulaçáo primitiva que pavimentam o caminho da expansáo da cafeicultura, ao arrepio da naturalizafáo do capital das interpretaçóes de Caio Prado Jr. e Celso Furtado.

Essa burguesia nascente tem importante ponte com a própria burocracia imperial, cujo projeto tem pretensóes hegemônicas contra as forças centrífugas, em sua interpretação, representadas pelas nascentes oligarquias regionais e locais. Essa burguesia năo tem projeto hegemônico, mas sua ligação com a burocracia imperial e com a própria formação do Exército lhe fornece os meios para impor uma organização primitiva da concorrência, ao contrário do paradigma, estranhamente neoclássico, que se insinua entre os dois grandes clássicos da interpretação da história econômica brasileira, Caio Prado e Celso Furtado, como se a concorrência se organizasse a si mesma. Luis Alves. de Lima e Silva é emblemático dessa fusáo de interesses entre a burguesia nascente do café na Província do Rio, o projeto hegemônico da burocracia imperial e a formaçáo do Exército: ele é a vertente latifundiário-burguesa do Exército, contra a vertente latifundiário-camponesa, cujo emblema é Osório, o Marquês de Herval. 
Pelo processo dessa luta, as revoluções (Cabanada, Balaiada, Sabinada, Confederação do Equador, Revolta dos Malés, Farroupilha e Praieira, já na metade do século XIX, esgotando e fechando o ciclo ) são degra(e)dadas à condição de rebelióes - regionais a simples episódios locais - contra uma tendência que estava escrita... nas estrelas. Coisa de marginais, de gente sem importância, contra a elite imperial. Desconhece-se o caráter de algumas transformaçóes econômicas que estavam na base das revoluçốes, para abastardá-las num funcionalismo necessário à construção dos grandes mitos nacionais. Nas dobras desse funcionalismo e sob os galóes do futuro Duque de Caxias, jazem as diferenças da formaçāo econômica, reduzidas de agora por diante a movimento de decadência, que aguardariam o apocalipse do café para uma nova chance sobre a terra. E a Questão Regional começa seu longo caminho de construção.

A unidade nacional mal resolvida é simultaneamente a resolução da questão do Estado nacional, a qual somente é assegurada na medida em que as questóes do mercado de trabalho e da terra são enquadradas pelas novas classes dominantes. Historiografia suspeita e teoria econômica impotente dáo-se agora as máos para encontrar o empresário schumpeteriano no desbravamento do Oeste paulista. A rigor, e novamente essa contribuição original é de Luiz Felipe de Alencastro, do que se tratou é menos de uma descoberta da superioridade do trabalho livre sobre o escravo e mais das rebelióes dos escravos, de um lado, e de outro, da possibilidade de que, em presença de terras livres, a fuga de escravos se transformasse em estabelecimento de quilombos - a lembrança de Palmares náo estava táo extinta - e mesmo em possibilidade de descontrole do processo de grilagem das terras. Entáo, o apelo ao imigrante torna-se a solução economicamente superior: na verdade, a social e politicamente mais segura, e um mercado de terras começa a emergir na região em expansão do café.

\section{Burguesia cafeicultora e burocracia imperial: a organização da concorrência e a degra(e)dação dos adversários}

No mesmo momento em que a regiáo do café resolveseus problemas de mão-de-obra e de terras, congela quase simetricamente os mesmos problemas de mão-de-obra e de terras nas demais regióes. Aqui, o desenvolvimento da questáo será mais apurado, para observar-se a constituição da Questão Regional. O café havia se expandido com máo-de- 
obra escrava; o Rio era seu grande abastecedor, ao contrário da tese furtadiana de que esse abastecimento provinha de Minas. Eis uma das primeiras fontes da acumulaf̧ẩo primitiva do café. Esgotado o ciclo do ouro, a expansão do café refaz a economia de Minas, agora como economia de subsistência. $O$ que vai congelar uma questão agrária e uma questâo do trabalho ou do mercado de trabalho naquele Estado.

Na tradição de Caio Prado Jr. e de Celso Furtado, acostumamonos a pensar na expansão do café como espécie de expansão da missão civilizadora do capital. Mas a adoção de uma solução via imigração européia para a questão da mão-de-obra na expansão do café implica a primeira e mais determinante segmentação do mercado de trabalho que estrutura a moderna economia brasileira. Segmentação que vai congelar o escravismo nas demais regióes do país, pelo fato de impor uma cisão entre os diversos mercados de trabalho que já se unificavam no país, à base mesmo da troca do excedente de escravos, que reforçava a legislação precedente à Abolição e anunciava o modo de produçăo de mercadorias. Troca entre Nordeste e Sudeste, extinção, finalmente, do tráfico, aboliçáo parcial da escravidão nas províncias do Ceará, Rio Grande do Norte, introdução do trabalho livre sob formas do aluguel dos próprios escravos - a que se referem tantos anúncios na imprensa da época para trabalhos fabris e de construçóes públicas, não se tratando, pois, de empregos domésticos.

E essa cisão reforça-se pelo aspecto étnico: introduz-se uma competição no mundo do trabalho pelos postos mais baixos, antes reservados apenas aos negros, agora disputados entre brancos imigrantes e negros; estes podiam (?) emigrar por sua conta e risco, enquanto os europeus contavam com a proteção de seus países de origem: Aqui encontrase uma das raízes mais fundas do estranhamento entre classes dominantes, elites dirigentes e mesmo vastas parcelas das classes médias abastadas do Sul e do Sudeste e os imigrantes vindos do Nordeste, que forma o pano de fundo do separatismo dos ricos em expansão hoje no Rio Grande do Sul e Paraná, sendo a seu modo uma espécie de limpeza étnica. Dá, ainda, um caráter peculiar ao conflito capital-trabalho, gerando uma das mais estranhas relaçóes, que só conheceu elementos atenuadores pela intervenção de um Estado autoritário, lembrando a Alemanha de Bismarck.

A historiografia e a moderna interpretaçăo histórico-sociológica da constituição dessa precoce segmentação étnica de um mercado de trabalho, que mal se constituía, silenciaram sobre o fator étnico que estava no centro da questão, uma espécie de preconceito ao revés. Para se ser progressista, e ver na adoção do trabalho livre a superioridade sobre 
o trabalho escravo, fez-se silêncio sobre a discriminação étnica que a imigração introduzia na estruturação do mercado de trabalho da regiáo em expansão capitalista, com pretensóes de dominaçấo. Tardiamente, essa discriminação étnica aparecerá na forma do separatismo dos ricos, versão ainda soft da limpeza étnica que os atentados dos grupos de skinheads neonazistas da Zona Leste da capital de São Paulo, contra rádios que fazem programas nordestinos, expressam dramaticamente.

De outro lado, acostumamo-nos também ao decadentismo que impregna a história das regióes, ao ponto de fazê-las desaparecer, para restar, apenas, a missão civilizadora do café. A força da demiurgia de Caio Prado e Celso Furtado levou a obscurecer um período que náo foi só de decadência, e somente agora a nova pesquisa começa a pôr em evidência a debilidade da construção de Caio e Furtado (v. particularmente Stein, 1957 e Singer, 1969). Desde a segunda metade do século XIX, a indústria têxtil começou a expandir-se no Brasil, até em razăo da própria Guerra de Secessão norte-americana, quando o algodão brasileiro alcança um lugar ao sol no mercado internacional. Segue-se daí, depois da recuperação do lugar da produção norte-americano nesse mercado, um esforço de industrialização, que se dá em todo o país, de alto a baixo. De Caxias, no Maranhão, a Valença, na Bahia, onde já na metade do século XIX havia uma unidade industrial com mais de 2000 operários escravos, grande mesmo para os padróes de hoje, passando por Pernambuco, Sergipe, Minas com Juiz de Fora (a Manchester brasileira, é bom não esquecer, apesar de Itamar), Rio de Janeiro, São Paulo, Rio Grande do Sul, num ciclo que vai até os anos vinte desté século. A saga de Delmiro Gouveia, que arrosta contra si todas as potestades da concorrência inglesa em aliança com seus. inimigos de classe dentro de Pernambuco, e sendo derrotado, até a eliminação física, vê perdidos os esforços de aproveitamento hidroelétrico do Rio São Francisco. Meio século depois, seu crime será redimido, abrindo nova era na industrialização do Nordeste. O processo desenvolvido foi, pois, de concorrência entre capitais, e o que foi capital, para ornamentar com uma frase de efeito, foi a organização da concorrência. Năo se tratou de autoorganização da concorrência, ou auto-regulamentação do capital, como nunca pode se tratar. Aqui entra o papel do Estado, de forma forte.

O papel do Estado esteve, especialmente, na utilizaçáo dos recursos públicos na sustentação e expansão da cafeicultura, sobretudo na organização da concorrência. Não se tratava, ainda, de regulamentaçóes de limitação da concorrência, nem sequer da proteçáo contra a dilapidação da força de trabalho. Aqui vai se tecer uma política de organização da concorrência - que é de liquidação dos outros capitais concorrentes 
- e uma política de alianças, de uns setores contra outros. Para não haver absolviçóes nem pelourinhos. A quem quer que tenha algum conhecimento das finanças do Império, não escapará dependerem estas, basicamente, das províncias da Bahia, Pernambuco e Minas. Nos termos de hoje, em que São Paulo discute a questão, elas tinham superávit sobre o que o Império nelas gastava. O Rio era o grande gastador, mas também arrecadador, e São Paulo já figurava como um grande perdulário. Eis a segunda fonte da acumulaf̧ão primitiva que alimentou a expansão cafeicultora, um mistério que nem Caio Prado nem Furtado explicaram: de onde saíram os recursos de capital do café? Dele mesmo? Mas como capital faz capital antes de ser capital? Pela acumulação primitiva: de um lado o Rio, com o comércio de escravos, de outro as fontes fiscais, drenando recursos das províncias superavitárias para as deficitárias. Caio Prado não explica o ocorrido. As fortunas do café surgirão quase como que por mágica. Mesmo o preamento de índios não terá sido capaz de realizar a acumulação primitiva, nem a acumulação de terras pelo bandeirantismo, num período em que não havia mercado de terras. Furtado não está no terreno teórico do marxismo $\mathrm{e}$, portanto, não tem necessidade de explicar: ele não tem uma teoria da acumulação de capital, e consegue ir apenas ao ponto da formação de capital, e para isto a cultura do café é auto-explicativa. Em que consistia essa acumulą̧ão primitiva? Nas garantias que o Império dava aos países de onde importava mãode-obra, no financiamento das ferrovias, que não foram custeadas pelo capital inglês, como diz a propaganda, no aval das operaçóes externas. Eis alguns excmplos.

Na República Velha os exemplos são mais fartos. São Paulo tenta, sozinho, bancar a sustentação dos preços do café nos mercados internacionais. Logo, essa funçăo é transferida para o Estado nacional. Divisas gastas nessa sustentação, que Villela \& Suzigan (1973), em livro do começo dos anos setenta, demonstraram já serem superiores à própria receita das exportaçóes, constituíam, concomitantemente, capital e recursos públicos. Pelo uso simultâneo da divisa, que amarrava, inclusive, a oferta monetária interna, e era tanto capital quanto recurso público, o Estado tanto subsidiava o café e obstaculizava a acumulação de capital em outros setores, quanto organizava a concorrência, impedindo a expansão de outros segmentos. É simples.

Portanto, a Questão Regional é, basicamente, a história da resolução da questão do mercado de força de trabalho, a qual vai ter consequiências sobre a irresolução da questão agrária. Ela é essa summa. O que não significa colocar no pelourinho São Paulo, como região por excelência do café, mas como centro da nova classe social que está revo- 
lucionando o modo de produção; nem absolver oligarquias regionais, mas tratá-las como aliadas da burguesia de Sáo Paulo que, em determinados período e processo, caminharam, em razão de seus interesses - e náo de afinidades eletivas do tipo ethos protestante-capitalístico à la Weber - para liquidarem seus concorrentes locais e regionais na estrutura de poder econômico e político. A Questão Regional é o resultado desses processos.

\section{Unidade oligárquica e dominação pelo mercado: a locomotiva puxando os vinte pagôes pazios}

Examinando-se mais de perto, pois, a unidade nacional compôs-se de um arquipélago de ilhotas oligárquicas, para o qual a literatura política já chamou a atenção reiteradamente; o conjunto de ilhotas, porém, não constituía uma ordem patrimonialista, nem a economia correspondia às ilhotas oligárquicas, havendo entre as duas esferas, como é evidente, troca, reforço, sustentação e, sobretudo, contradiçâo. Surda luta entre formas distintas dos capitais agrários $\mathrm{e}$ industriais - e agroindustriais - e luta aberta nos períodos em que a contradiçăo tornava-se insuportável. A dominaçáo econômica da regiāo, cuja atividade estava em expansáo - na literatura mais clássica atribuída à expansão da demanda internacional por café -, dá-se através do pacto das ilhotas oligárquicas, que pela política (Polanyi, 1970) operou uma unificação econômica que o mercado não foi, nunca, capaz de realizar. Até os anos da revolução de 1930, e muito mais para a frente, até praticamente a década dos cinqüenta, continuaram a existir, com leis e movimentos reprodutivos relativamente independentes, economias regionais, já então derrotadas do ponto de vista da concorrência mais geral entre os capitais de todo o país, mas suficientemente fortes para fecharem-se sobre si mesmas. Será apenas com os incentivos fiscais criados pela SUDENE, e logo copiados para a Amazônia, que as economias regionais sucumbirão.

A contradição entre uma ordem econômica capitalista e uma ordem política oligárquica não é novidade alguma; o Japão é assim. Isto tem dado azo a teorizaçóes sobre a economia patrimonialista do Brasil, sobre organização patrimonialista da sociedade, sobre Estado prebendário, e sobre todas as outras armas retiradas do arsenal weberiano. Que é rico mas, neste caso, impropriamente utilizado.

A Revolução de $\mathbf{3 0}$ amplifica a unificação do mercado, derruba as fronteiras estaduais, criando o espaço para a circulação ampliada das mercadorias, o que significa imenso reforço à acumulaçáo de capital, 
pelo aumento da velocidade da sua circulação, pela mais rápida metamorfose da forma-mercadoria para a forma-dinheiro e, desta, novamente para a forma capital-dinheiro. Mas não há, concomitantemente, circulação ampliada dos capitais, travada pela própria fratura na unidade nacional, ou pelas formas inacabadas ou imperfeitas de sua resoluçăo. Para tanto, seria preciso ter resolvidas as questóes agrária e do mercado de trabalho, as quais são precisamente duas travas do processo de acumulação, ou melhor dizendo, da possibilidade do processo de centralização do capital, que é do que se trata ao falar-se de circulação de capitais. Não há transferência de capitais entre as diversas regiōes do país, uma das formas concretas que a centralização adquire quando a unidade nacional se nacionaliza para o capital, pelas vias do capital. Tal fato só passou a existir no Brasil quando o Estado criou o modelo institucional, seja pela forma fiscal, seja pelo câmbio favorecido. Depois, de maneira mais sofisticada - já adiantada a década de cinqüenta -, ele criará o sistema de incentivos fiscais; os juros reais negativos via sistema de crédito estatal, compreendendo todas formas de centralização do capital, que o próprio capital não é capaz de operar sem a regulaçáo do Estado. Antes disso, o que acontece, e com maior frequiência, é a implantaçăo de grupos econômicos do Nordeste no Sudeste, a exportaçáo de capitais da regiāo mais pobre para a regiāo mais rica, mas feita diretamente, sem a intervenção do que se chama, modernamente, de mercado de capitais e nem sequer do mercado de crédito.

Gradualmente, com a própria expansão da circulação de mercadorias, São Paulo vence, domina, mas não hegemoniza. Porque seu mecanismo de dominaçảo é o mercado, e este é insuficiente para forjar a hegemonia. Derrubadas as fronteiras estaduais, a industrialização avança celeremente. Durante uma década, que para todo o mundo desenvolvido foi de profunda depressão, a economia nacional iniciou um movimento ascensional, transferindo o motor da divisão social do trabalho da agricultura para a indústria, cujo fôlego final somente expira rigorosamente nos anos 80.

No bojo da revolução chamada keynesiana, que na verdade é a resposta à crise mais criadora neste século, o Brasil se adianta $e$ inova. $O$ nacionalismo brasileiro da industrialização não é senáo uma versão keynesiana do que os liberais chamarão intervençäo do Estado na economia.

\section{A hegemonia inacabada: as difíceis relações de São Paulo com a diversidade nacional}

Não se irá reconstituir todo esse processo. Importa reter aqui ape- 
nas um dos raros momentos em que a hegemonia esteve quase por completar-se, quando São Paulo esteve na cabeça de todos, principalmente dos que migravam em sua direção, e dos que permaneceram nas regióes menos desenvolvidas. Importa reter um dos raros momentos em que, não por nostalgia dessa hegemonia inacabada, mas para tirar as conseqüências dela, a liderança de São Paulo quase refez ou fez a nova unidade nacional, consolidando, pela analogia traumático-ortopédica, a velha fratura do século XIX, dando início a um processo de definitiva resoluçăo da Questão Regional. Desde logo, uma das insuficiências responsáveis pelo mais retumbante e, desta feita, definitivo fracasso, esteve em que o processo básico dessa quase hegemonia foi sempre o mercado.

Exatamente na passagem dos anos quarenta para cinquienta, e alcançando até o final da década de cinqüenta, esteve-se perto da construção de uma unidade nacional forjada pela hegemonia paulista. Foi o momento em que, da liderança indiscutível da produção industrial, emergiu a construção do imaginário. Alçou vôo no imaginário popular a firme conviç̧áo de que havia um futuro no Brasil, e esse futuro tinha um nome e esse nome era São Paulo. No fusca, hoje só motivo de chacota, nos homens mal acomodados que começavam a povoar as novas periferias industriais, no pai dizendo "vai, filho, cresce, para ir trabalhar em São Paulo", havia, menos que miséria, a construção de uma hegemonia. Isto é, de um mito, de uma visão de mundo, de uma forma de conceber, de uma unidade que, de alto a baixo, repete a mesma ladainha. Esta é a definição gramsciana para hegemonia.

Quando meu tio João Rodrigues, então jovem tenente da Brigada Militar de Pernambuco, visitou São Paulo, entre 1946-1947, e ouviu de César Lattes a promessa de, dentro em pouco, alimentar todas as indústrias, casas e ruas com a energia elétrica das pilhas atômicas, na cabeça de um anônimo oficial de polícia militar de Pernambuco construía-se a hegemonia de São Paulo.

Amavelmente, Alfredo Bosi me recorda que o imaginário nacionalista, a ideologia nacionalista foi muito mais um produto do Rio, numa longa derivação que começou como uma elaboração da direita e terminou como uma teorização da esquerda. O ISEB, como instituição coroadora dessa ideologia, o Exército (e a notável ausência de paulistas no Exército, como se comentará adiante), com o Clube Militar, são instituiçóes do Rio. A produção intelectual paulista nas ciências sociais sempre foi avessa ao nacionalismo, e o mais notável de seus grupos intelectuais, justamente conhecido como o Grupo de $O$ Capital, elaborou sofisticada interpretação do Brasil que, deitando raízes em Caio Prado Jr., passa ao largo do nacionalismo, não dialoga com ele e elabora 
na vertente da classe social e não da nação. Tem razão Alfredo Bosi. Mas o imaginário de que estou falando era o do povo, e não o dos intelectuais. E o povão, que emigra, pois a migração é um fenômeno de classes sociais, tinha os olhos fixos em São Paulo. Tal como o ditado dizia, São Paulo era para se trabalhar, e o Rio para se arranjar emprego.

Esse processo abortou e já no começo dos anos sessenta era visível o esgotamento da possibilidade de constituiçăo da hegemonia paulista. O deslocamento do imaginário para o tema das reformas e da revolução - não importando aqui quão plausível fosse ou pudesse ter sido indica claramente que a burguesia havia perdido sua oportunidade de plasmar o país à sua imagem e semelhança. A burguesia perde a liderança do processo, ninguém mais imagina migrar para Săo Paulo embora ainda o façam cotidianamente - e os ícones do breve período são substituídos na ação política e no imaginário popular, para nunca mais voltarem. Mesmo quando o neoliberalismo se apresentar, nos dias de hoje, com sua cara hedionda disfarçada nas lantejoulas e paetês da modernização e no banho de champanhe dos Champs Elysées, ele é cansaço da burguesia, não mais ousadia. Quando a miséria é um pesadelo e não mais desafio, passou a hora da hegemonia.

É possível listar algumas das condiçôes não cumpridas, que explicam parcialmente o fracasso da hegemonia inacabada, ou o inacabamento do mito. Um dos pontos mais visíveis desse fracasso diz respeito ao Estado, e particularmente à formação de sua burocracia. Embora a burguesia paulista - sujeito principal da economia capitalista brasileira tenha sido, sempre, assaz freqüentadora dos gabinetes estatais, e beneficiada por uma longa série de subsídios estatais, que começou desde o Império - ao contrário da lenda de uma burguesia auto-suficiente, de costas para o Estado, construída, com perdão do trocadilho, pelo Estadão -, a burguesia paulista jamais se preocupou com o próprio Estado nacional ou com a formaçáo de sua burocracia. Ao contrário de sua atitude dentro do Estado de São Paulo, onde modelares instituiçóes como a própria USP e todos os grandes institutos, Adolfo Lutz, Butantan, Biológico, marcaram verdadeira revolução, a burguesia paulista virou as costas para o Estado brasileiro do ponto de vista dos interesses mais gerais que cabia ao Estado atender.

Em todos os aparelhos ideológicos, para usar a expressão althusseriana, a não presença de São Paulo é notável. Na Igreja Católica, de que o primeiro cardeal paulista era pernambucano e seu grande e nobre cardeal de hoje, que Deus o mantenha por muitos e muitos anos, contra a vontade de Wojtyla, é ... catarinense. Não há muitos generais paulistas, $\mathrm{e}$ isto não se deve, certamente, ao fato de náo haver colégios militares 
em São Paulo, como uma sociologia de araque pode imediatamente deduzir. A Academia da Força Aérea localiza-se em Pirassununga, onde o número de paulistas também é reduzido, enquanto no ITA, por muito tempo representando a vanguarda da formação da tecnologia de ponta, o número de paulistas sempre foi proporcionalmente maior que em qualquer outra instituição militar. Não há generais paulistas porque o sucesso está em outro lado. Apesar de, na galeria de ex-ministros da Fazenda, Sáo Paulo comparecer com uma quota notável (mesmo quando não paulistas de nascimento, paulistanizam-se rapidamente pelos interesses. De Oswaldo Aranha a Mailson da Nóbrega, essa é a lição da exceção, porque a regra náo precisa de demonstração), a burocracia do ministério permaneceu notavelmente não-paulista. Quando Delfim Netto lá chegou, levando toda sua equipe, ao contrário do que fizeram os anteriores ministros paulistas, o Ministério da Fazenda ficou conhecido como Recreio dos Bandeirantes, apelido que o humor carioca logo pespegou para marcar o fato de serem táo desconhecidos quanto a entáo remota praia para além da Barra da Tijuca, no próprio Rio.

Mui recentemente, há cerca de três anos, entrei nos bastidores do $\mathrm{CNPq}$, como membro de um dos Comitês Assessores. Há muito, ouvia de meus colegas paulistas que o $\mathrm{CNPq}$ era o reino da incompetência dos nordestinos, e por isso, conclusão óbvia mas obscura para mim, a ciência não caminhava. Constatei, pelos sobrenomes e nomes próprios, sobretudo porque sou do Nordeste - náo precisaria treino sociológico para tanto - que, efetivamente, a maior parte da burocracia do CNPq é constituída por não-paulistas, isto é, nordestinos e seus descendentes, mas também goianos, mineiros. Indo ao ponto, a grande incompetência é dos cientistas, particularmente a dos radicados em São Paulo, a maioria absoluta no país, que jamais ligaram para o CNPq, e mais, nunca se abalançaram para largar-se de Sáo Paulo e organizarem a promoção da pesquisa científica e tecnológica inicialmente no Rio e há mais de vinte anos em Brasília.

Apesar de tudo, a burocracia ainda consegue funcionar devido aos nordestinos, goianos, mineiros, que, faltos de oportunidades melhores em seus Estados, arriscam-se em Brasília e nos demais postos da administração federal. Mas essa seria uma explicaçáo ingênua e comprometida, afinal de contas. Ingênua, porque há fisiologismo não apenas em Brasília, e há de montão, mas o surpreendente, há mais fisiologismo em São Paulo que em todas as repartições federais somadas. O fisiologismo das empresas junto com os diversos níveis de governo em Săo Paulo é competente; talvez seja esta a diferença. Mas faltam também paulistas no Itamaraty, no Banco do Brasil e em algumas das melhores burocracias que o país já teve. O que se quer dizer é ter São Paulo ficado isolado: 
não conheceu o Estado brasileiro por dentro, sua máquina, seus modos de funcionamento.

Jânio, com seus característicos bilhetes, que os apologetas logo se encarregaram de transformar em revoluçăo na administraçăo, revelava tão somente, através deles e por eles, total desconhecimento e ignorância dos mecanismos e das entranhas da máquina do poder federal. Porque o presidente despacha documentos oficiais, não apropriados para a emissão de opiniōes pessoais, ainda que sejam dố presidente, procedimento que qualquer mineiro, baiano, pernambucano, gaúcho sabe por treino $\mathrm{e}$ necessidade. Não se está postulando aqui que a burocracia deveria ter sido preenchida por paulistas, o que seria economicismo primitivo, reduçáo do político ao econômico, e equivalência das estruturas estataisoficiais às econômicas, de forma primária e elementar. O que se quer pôr em relevo é que, se a burguesia dominante de São Paulo alguma vez teve projeto hegemônico, algo como uma ética paulista nunca fecundou o Estado brasileiro, visto do ângulo da formação de sua burocracia.

O que não significa que a administração do Estado no Brasil fosse retrógrada: pelo contrário, a burocratização, no sentido positivo atribuído por Weber, é marcante nas instituiçóes da meritocracia do novo Estado brasileiro, como o DASP, com os concursos públicos para preenchimento dos cargos e as regras da modernizaçáo administrativa, o Banco do Brasil, a própria burocracia do Itamaraty, o BNDE, o IBGE de antes das súbitas mudanças dos índices que apurava, feitas para esconder o desastre dos planos ou para baralhar as reivindicaçōes dos trabalhadores, a reorganização das próprias Forças Armadas logo depois da Segunda Guerra, as grandes estatais etc. $O$ desmantelamento da burocracia estatal começa como um projeto sistemático de Roberto Campos, ainda no primeiro governo da ditadura. Mas isto é, também, outra história. Enquanto a maioria das empresas privadas patinava em administração personalista e primitiva, de que dá prova a liquidaçáo de grupos outrora poderosíssimos, como Matarazzo e Jafet, precisamente de São Paulo, os quais puderam manter-se à cabeça de seus vastos impérios conglomerados avant la lettre enquanto manipulavam as rédeas do poder.

A relaçáo de São Paulo com a formação da cultura brasileira é igualmente problemática. Esse campo é suficientemente minado para extrair-se conclusóes sobre a relaçáo entre dominaçáo econômica e elaboraçâo cultural hegemônica. Arrisco-me, no entanto, sem postular qualquer relaçáo causal - aceitando, como a maior parte da crítica já fez, que houve uma nova elaboração cultural em São Paulo com o advento da industrializaçáo, sendo a Semana de Arte Moderna o marco 
dessa nova relação - a dizer que a interpenetração, a fecundação, entre a cultura de São Paulo e a das diversas regióes brasileiras não ocorreram. Agora, sob a égide da induistria cultural, há um intercâmbio que é notável sobretudo na música popular, mas já não se trata de hegemonia; a liderança que Sáo Paulo assumiu, desde há algum tempo, no campo da produçáo intelectual e na imprensa escrita, não é um projeto de hegemonia burguesa. Em muitos casos, é o resultado, sobretudo na área da produção intelectual, de um projeto de hegemonia contraburguês, que tampouco se realizou plenamente.

Nunca houve uma arte, uma literatura, uma pintura nacionais, com a marca de São Paulo; a que existe é a do Rio. É fácil afirmar que essa marca deve-se à condiçăo de antiga capital, o que é verdade, mas não toda a verdade. $O$ real é que as artes nacionais sáo uma espécie de síntese da diversidade regional do país, elaborada cariocamente. Mas a simples condição de capital não responde por tudo, pois Washington não é o grande centro das artes nos EUA, enquanto é possível encontrar nos museus de New York, no MoMa, no Metropolitan, no Guggenheim, as marcas de um projeto hegemônico da burguesia norte-americana. Parte do enigma pode ser decifrado decodificando-se as relações de classe na sociedade brasileira, e particularmente as relaçóes desta com o Estado: decididamente as relaçóes sociais no Brasil foram moldadas segundo um padrão que requereu, desde a colônia, formas estatais, o que se projetou, também sobre a cultura. A burguesia, portanto, sempre foi estadocrata, $e$ iniciativas culturais liberais não são muito comuns no país. Projetada para o campo da hegemonia, essa estadocracia das relaçóes sociais revelou-se mortal.

De outro lado, migravam para São Paulo trabalhadores de todo o Brasil, e particularmente de Minas e do Nordeste. Intelectuais, ou membros das classes médias, mais aptos para a produçáo cultural, por razóes de classe, evidentemente, não migravam para Săo Paulo, mas para o Rio. $\mathrm{E}$ geralmente para serem funcionários públicos. Tome-se as profissões $\mathrm{e}$ origens sociais de José Lins do Rego, Raquel de Queiroz, José Américo de Almeida, Graciliano Ramos, Guimaráes Rosa, Carlos Drummond de Andrade, e mesmo no passado mais remoto, José de Alencar e Machado de Assis. Escritores, romancistas, poetas, e diplomatas, fiscal do imposto de consumo, funcionário do Ministério da Educaçăo, funcionários públicos em geral, imigrantes de Minas e do Nordeste, ao lado, evidentemente, de Machado, carioca. A simbiose entre burocracia - espécie de mecenato implícito, simulacro do mecenato explícito que o Estado nunca fez, ou fez mal e porcamente e substituto do mecenato que a burguesia nunca ousou - , destino de classe e produção cultural explica o 
papel do Rio na formaçáo da cultura nacional e a simétrica ausência de São Paulo.

As artes paulistas são muito mais de São Paulo, fechadas sobre si mesmas. Mais recentemente, no capítulo da grande indústria cultural, no cinema, o esforço fracassado de São Paulo atesta não apenas a inviabilidade econômica do empreendimento, mas a impotência de construção de uma indústria cultural que lidava mal com a diversidade regional do país. Os filmes da Vera Cruz foram náo apenas uma tentativa vá de fazer filmes sérios para exportaf̧ão: eles fracassaram porque não passavam de pastiches europeus, e por isso, não diziam nada a alguém fora de São Paulo. Como a própria população local, nos estratos de classe que formavam a opiniáo sobre o cinema, já estava acima desse pastiche, então a Vera Cruz não falava sequer aos paulistas. $O$ maior comediante paulista, Mazzaroppi, é um desconhecido no resto do Brasil. Seu humor caipira náo dizia nada ao resto do país, e apenas agora seu talento pode ser reconhecido. Mas como fenômeno de massas, para os demais estados brasileiros, ele foi um tremendo fracasso.

A incomunicabilidade paulista é tão dramática que a própria televisáo, que tal como a Rede Globo o faz, lida com a diversidade regional em termos idiossincráticos, como pastiche, tem sede no Rio e não em São Paulo. Porque, mesmo no seu reducionismo pobre, ela consegue lidar com a diversidade regional no Brasil, enquanto Săo Paulo não consegue fazê-lo. Esse isolamento paulista, que alguns interpretarão como a ilha de capitalismo num mar de formaçóes precapitalistas, versão apenas mais elaborada da sempre arrogante locomotiva que puxa os vinte vagóes vazios, demonstra que o tempo da construção da hegemonia havia passado irremediavelmente. Mesmo um grande talento paulista, como Chico Buarque, para alçar vôo e transformar-se em unanimidade nacional, mudou-se para o Rio para não ficar condenado ao que alguns chamaram samba paulista, do qual se tem alguns excelentes exemplares, como o saudoso e inimitável Adoniran, mas incapaz de constituir ou formar escola; incapaz de se tornar nacional.

\section{As conseqüências da impotência hegemônica da burguesia paulista}

Essa hegemonia inacabada, essa dominaçáo apenas pelo mercadu, tem enormes conseqüências, e não fosse por elas, não valeria a pena este debate. Não se trata, pois, de reivindicaçáo regionalista, no sentido de que se a hegemonia tivesse sido de outra regiáo, a obra teria sido melhor 
acabada. Nem se trata, tampouco, agora, de bradar pelo acabamento dessa hegemonia. Seu tempo passou, e desde há muito, os problemas e as fraturas da sociedade que a ausência de hegemonia deixou são tarefas das novas forças sociais e políticas, contra-hegemônicas, antiliberais, para além do mercado. E, finalmente, não se trata de pôr São Paulo no pelourinho: aqui a equivalência entre Sáo Paulo e a burguesia deve ser entendida como a expressão máxima da potência burguesa no Brasil, à época da hegemonia possível. De fato, a territorialidade, o arcabouço jurídico-político do Estado, sem nenhum reducionismo vulgar, constituíam forças produtivas burguesas, assim como o Estado-nação da época do imperialismo constituiu, à sua época, igual força produtiva imperialista. A Royal Navy que o diga. As outras burguesias regionais no Brasil também utilizaram o poder de seus Estados circunscritos. A freqüente redução entre Nordeste e latifúndio rural, se hoje já corresponde menos à verdade dessa relação de mútua representatividade substitutiva, no passado já foi bem mais real.

A hegemonia inacabada criou um monstro, que foi, durante muito tempo, uma aliança de interesses entre a burguesia industrial e oligarquias agrárias retrógradas. $\mathrm{O}$ famoso mistério do país que se industrializava sob a batuta de dois partidos de base rural - PSD e UDN - é esclarecido quando pensado de outra forma: tratou-se da aliança entre a burguesia industrial e poderosas e reacionárias oligarquias rurais, latifundiários para sermos mais precisos. Esse monstrengo deixou intacta a questão agrária, irresoluta a questão do mercado de trabalho no campo, com o que reiterava a própria questão agrária e, por extensão, também sem resolução a questão negra no coração da própria industrialização. Oitenta anos depois da Abolição, a Lei Afonso Arinos ainda tentava exorcizar a discriminação racial em pleno desenvolvimento do Brasil urbano, cuja estaca da segmentaçáo étnica do mercado de trabalho fora definitivamente fincada pela solução da imigração estrangeira para à expansão da cafeicultura em São Paulo. E todas as disposiçóes da CLT que procuraram anular aquela ancestral divisáo étnica do trabalho foram impotentes até agora, assim como os renovados dispositivos da Constituição de 1988.

O capítulo dos direitos civis pagou alto tributo à hegemonia inacabada, à simples dominação pelo mercado, a essa trama entre oligarquias retrógradas e uma burguesia vitoriosa pela manipulaçáo da violência como organizadora da concorréncia. Esse é, no fundo, o tema de Roberto Schwarz de ideias fora de lugar e em toda sua exploração do romance machadiano. Não há barreiras para a ignomínia, e o liberalismo sempre foi uma caricatura. Não porque inexistisse espírito de lucro; ao 
contrário, a sociedade está pejada dele. Mas o lucro é construído numa trama na qual violência privada e violência do Estado organizam a espoliação do escravo e a própria concorrência entre os que deviam ser iguais: os próprios burgueses.

Essa aliança, ao contrário da teoria da expansão da industrialização como mancha que se expande a partir de um centro, foi responsável pelo aborto da industrialização em várias regióes do país, em vários Estados, então províncias. A liquidação de vários empreendimentos não ocorreu porque eram feudais: feudal ainda é a Votorantim, assim como a Cidade de Deus, do Bradesco, em Osasco. Ou todo o Japão. A liquidação se deu porque a aliança entre a burguesia cafeicultora e posteriormente a burguesia industrial com latifundiários retrógrados em todo o Brasil utilizou os poderes do Estado para manejar a concorrência, para organizar a concorrência. De várias maneiras, como já foi sugerido e exemplificado, às quais não é preciso voltar.

Esse tipo de aliança sustentou um sistema político que entrou em colapso repetidas vezes, mas foi reposto quase sempre pelo poder das armas a serviço da burguesia industrial, mesmo quando já havia perdido a exclusividade da dominaçáo econômica, dividida agora com forte parcela da burguesia internacional. O golpe de 1964 é tragicamente o epílogo de uma burguesia sem brilho: enquanto as forças populares lutavam por uma Reforma Agrária que, no fundo, era uma das formas de resolução da velha Questão Agrária, a burguesia industrial unificava-se com o velho latifúndio e com a burguesia internacional - com quem já estava unificada do ponto de vista econômico -, dando o golpe de graça na armaçáo ideológica de sua própria hegemonia, na sua última mani: festação, de que apenas restava como porta-voz o Partido Comunista Brasileiro. O Nordeste parece ser o centro da revolução: ele é apenas a demonstração de sua impossibilidade, de um lado, e do fracasso definitivo da burguesia brasileira, de outro. A reivindicaçáo de reforma agrária no Nordeste não se destinava a viabilizar o capitalismo no campo no Brasil, mas a solucionar a questão agrária e a questáo do mercado de trabalho, e sua summa, a questão regional. O ponto de fuga da resolução é dado no Sudeste, mas o estrondo, no Nordeste.

Já mais recentemente, quando a ditadura dava sinais de incapacidade para seguir, e o voto popular transformou um simulacro de oposição em real, em 1974, a ditadura interveio para, alterando as proporcionalidades da representação, manter a sustentação congressual do regime militar, fazendo com que um eleitor de Roraima ou do Acre valha dez de São Paulo. Mas o importante é dizer que essa proposição é basicamente paulista, verbigratiae, da burguesia, que tinha o agora humo- 
rista Delfim Netto, um ano antes como todopoderoso ministro da Fazenda, e voltou a tê-lo ainda com Figueiredo.

Uma hegemonia inacabada significou, do ponto de vista dos direitos sociais, pesada herança. Tal como na história de países cuja unidade também foi realizada autoritariamente - a Alemanha é o exemplo mais notável -, a ausência de hegemonia torna a burguesia tão irresponsável politicamente que o próprio autoritarismo é levado a corrigir sua irrefreável volúpia dilapidadora. Assim como Bismarck inaugurou o Welfare State, em parte para cortar a progressão do movimento socialista, mas também para educar sua própria burguesia, no Brasil o autoritarismo de Vargas teve que apropriar-se dos projetos longamente elaborados pela própria experiência operária, e transformá-los na CLT e nos Institutos de Previdência.

Uma hegemonia inacabada teve por conseqüência, por fim, o culto mais completo e acabado do autoritarismo, esse permanente ciclo pendular entre populismo e intervenção militar. O populismo foi a forma por excelência da irrupçáo do proletariado na política, rompendo o cerco da questão social como caso de polícia. Mas o populismo é forma por inteiro dependente da tutela exercida pelo Estado sobre os sindicatos, frequientemente atribuída a uma pura relaçáo entre movimento operário e Estado, que esconde a parte da burguesia nessa organização da questáo social. Formas gêmeas, populismo e autoritarismo são criaturas desse inacabamento, que deixaram o país, à beira do século XXI, com uma estrutura política infantilizada. Apenas nos últimos dez anos, a rebeldia, a iniciativa da sociedade civil, sobretudo dos sindicatos operários, o nascimento de uma classe média moderna, foi capaz e está sendo capaz de trazer o país aos umbrais da modernidade. Classe social e individualidade são, agora, perceptíveis. É visível já um projeto que dispensa a tutela do Estado, mas não lhe dá as costas. Uma nova cultura, hegemônica, nascida das duras experiências da ditadura, do novo operariado, das novas classes médias, de uma sociedade plural, está emergindo. A hegemonia burguesa, inacabada, está dispensada de seu papel, que não soube cumprir. Mas o desastre que legou não foi pequeno e $o$ atraso que gerou apenas pode ser reparado a duras penas.

\section{Referências bibliográficas}

ALENCASTRO, Luiz Felipe de. Memórias da Balaiada: introduçăo ao relato de Gonçalves Magalháes. Novos Estzudos Cebrap, São Paulo, n.23, p.7-13, 1989.

Le commerce des pipants: traite d'esclapes et " pax lusitania" ans l'Atlantique Sud.

Paris, tese (doutoramento) apresentada à Université de Paris X, 1985/86. 3 v. 
COHN, G. (org.). Adomo . São Paulo, Ática, 1986.

FURTADO, Celso. Formaçāo económica do Brasil, 8a ed. São Paulo, Nacional, 1968.

GRAMSCI, Antonio. Los intelectuales y la organización de la cultura. Buenos Aires, Ed. Lautaro, $1972.183 \mathrm{p}$.

HORKHEIMER, Max \& ADORNO, Theodor W. La dialectique de la raison. Paris, Gallimard, 1974.

MARX, Karl. A chamada acumulaçāo primitiva. In: O Capital: crítica da economin política . Rio de Janeiro, Civilizaçáo Brasileira, 1980.

NOVAES, Fernando A. Portugal c Brasil na crise do antigo sistemna coloninl (1777-1808), $4^{\mathrm{a}}$ ed. São Paulo, Hucitec, 1986.

OLIVEIRA, Francisco de. Elçgin parn umn Re(li)giño: Sudene, Nordeste. Planejamento c conflito de clnsses. Rio de Janciro, Paz e Terra, 1977.

POLANYI, Karl. The gruat transformution. Boston, Beacon, 1970.

PRADO JR., Caio. Histrrin do Brrasil, 7ª ed. São Paulo, Brasiliense, 1962.

REIS, Elisa Maria Pereira. The agrarian roots of authoritarian modcrnisation in Biazil, 1880-1930. Cambridge, MIT, Tese de Doutoramento, 1979.

SCHWARZ, Robert. Um mestre na perifcria do Capitalismo: Machado de Assis. São Paulo, Duas Cidades, 1990.

SINGER, Paul I. Desenvolvimento urbrnno e poptulaçño. São Paulo, Nacional, 1969.

STEIN, Stanley J. Origens e cvoluģão da indhistria têxtil no Brasil - 1850-1950. Rio de Janeiro, Campus, 1957.

VILLELA, Annibal Villanova \& SUZIGAN, Wilson. Politicn de governo e crescimento dn economia brasilcira (1889-1945). Rio de Janeiro, IPEA/INPES, 1973.

WEBER, Max. A ética protestante co ospirito do Capitnlisno. São Paulo, Pioneira, 1981.

\section{Resumo}

A Questão Regional, que no Brasil classificamente refere-se ao Nordeste, constituiu-se no século XIX, como resultado da forma de resolução das questóes do mercado de trabalho e da terra, pela economia em expansão, no caso a cafeicultura capitalista do Sudeste. Depois de ter anulado seus concorrentes, pela violência física (repressão às revoluçōes regionais) $\mathrm{e}$ pelo uso dos recursos fiscais para autoincentivar-se, numa forma privarista, a burguesia paulista-cafeicultora revela-se incapaz para o exercício da hegemonia. Os anos 40 e 50 deste século foram a última oportunidade desperdiçada para reparar um processo fratuado e resolver a Questão Regional quando São Paulo não apenas sediava o poder industrial, como constituía a esperança. Novas forças sociais e políticas, complexamente maruradas nas duas últimas décadas, são agora os principais atores, aptos a resgatar o país e a Nação para a modernidade, mas a herança da hegemonia inacabada deixou um longo roteiro de desastres, 
que cabe, precisamente, desfazer. O estudo da Questão Regional, menos que um plaidoyer nordestino, pode ser a chave para a compreensāo daquela herança.

\begin{abstract}
The Regional Question, which in Brazil traditionally refers to the Northeast, developed originally in the nineteenth century as a result of the manner in which economic expansion, namely capitalist coffee agriculture in southeastern Brazil, resolved the issue of land and labor markets. After having eliminating its competitors, either through the use of force (suppression of regional revolts) or through fiscal incentives for their own private benefit, the coffee-growing bourgeoisie of São Paulo State proved incapable of exercising hegemony effectively. During the 1940s and 50s, the last chance of mending a fractured process and resolving the Regional Question were wasted, as this was a period when São Paulo not only concentrated industrial power but also constituted the nation's principal hope. New social and political forces, which have matured in a complex fashion over the last. two decades, have become the main actors most capable of recovering the country and the Nation in terms of modernity, though they inherit an incomplete hegemony that has left a long line of disasters in its wake, which are precisely what must be undone. An analysis of the Regional Question, rather than simply a northeastern plaidoyer, may provide the key to understanding such an inheritance.
\end{abstract}

Francisco de Oliveira, economista, é professor titular do departamento de Sociologia da Faculdade de Filosofia, Letras e Ciências Humanas (FFLCH) da USP, presidente do Centro Brasileiro de Análise e Planejamento (Cebrap) e pós-doutorado pela Escola de Altos Estudos em Ciências Sociais de Paris. Desenvolveu atividades profissionais na Sudene, empresas de consultoria, instituiçōes de pesquisas estrangeiras e programas internacionais de desenvolvimento. É autor, entre outros, dos livros "Collor, a Falsificação da Ira" (1992), "O Elo Perdido" (1987), "A Economia Brasileira" (1981) e "O Banquete e o Sonho" (1976)

Conferência do Mês do IEA feita pelo autor no dia 31 de março de 1993. 